\title{
Pós-modernidade sem modernidade
}

Igor Zanoni Constant Carneiro Leão*

Muitos autores ligados à discussão sobre as características da chamada pósmodernidade, como Zygmunt Bauman, que discutimos em uma resenha com Demian Castro em outra parte deste número do Boletim, realçam que a sociedade atual cria condições materiais e emocionais extremamente velozes, mais velozes do que seria necessário para consolidação em hábitos e rotinas das formas de viver, agir ou sentir.

Nessa sociedade, capacidades transformam-se rapidamente em incapacidades, as formas de ação envelhecem antes de serem aprendidas por completo e é impossível aprender com a experiência. A vida se torna precária vivida em condições de incerteza constante, tornando-se uma sucessão de inícios e reinícios, habilidades e conceitos se tornam obsoletos assim como produtos de consumo ditados pela moda, atingindo mesmo nossas casas, roupas, diversões e qualificações profissionais. Esta forma de viver foi examinada particularmente em Vida Líquida, de Bauman, mas está presente como objeto de análise em diversos outros autores que estudaram o período após os "trinta anos gloriosos" entre o pós-guerra e o fim de Bretton Woods.

A dificuldade das economias avançadas em alavancar o crescimento de forma sustentável em uma sociedade com dominância crescente de mercados livres, desregulação da previdência social, do trabalho, somando-se a crise dos sindicatos promovida pelos próprios governos e órgãos internacionais, em uma palavra, a globalização gerada por meio de um crescente neoliberalismo, tão bem estudado por Naomi Klein em A Doutrina do Choque ou pelos documentários de Michael Moore, são os principais responsáveis por essa instabilidade aguda que atinge cada cidadão individualmente, cada vez mais só diante das condições de sua vida material, social, emocional, e assim por diante.

Interessante para nós é que essa discussão foi pensada para dar conta do que ocorre nas economias avançadas. Assim, ela começa, no livro Medo Líquido, de Bauman, com a desregulação em uma sociedade avançada dos mecanismos de seguridade social que promoviam proteção para seus membros e uma possibilidade de planejar e prever sua vida, pelo menos em grande medida. Este ponto foi também levantado por Richard Sennett em $A$

* Doutor em Economia pela UNICAMP. É professor associado do Departamento de Economia da Universidade Federal do Paraná. Endereço eletrônico: igorzaleao@yahoo.com.br. 
Corrosão do Caráter e por Robert Castel em As Metamorfoses da Questão Social, entre outros textos e autores. Entretanto é num país periférico e dependente como o Brasil que essa vida líquida se apresenta de forma crucial. Ao mesmo tempo ela não se liga a um tempo específico no desenvolvimento do nosso capitalismo.

Ao contrário, desde os primórdios da nossa formação nos apresentamos como uma sociedade em que o trabalho é um labéu ou um privilégio de poucos. Nosso mercado de trabalho, mesmo depois do início da nossa industrialização e de nossas primeiras leis trabalhistas após 1930, sempre foi fraturado, marcado por um grande segmento informal, salários médios baixos e um grau pequeno de proteção social. Mesmo com a generalização da educação fundamental e média e com o sistema único de saúde, entre outros indiscutíveis avanços nesse padrão de proteção, o ensino é precário, em grande medida realizado por caras escolas particulares com uma lógica diferente das escolas públicas, a saúde é atendida também de forma insuficiente e os ganhos com o desenvolvimento não são passados para as camadas mais pobres da população. Nossa concentração de renda é quase ímpar no mundo assim como nossa concentração da propriedade e de oportunidades.

Esse quadro não foi alterado profundamente pelo avanço da industrialização e pela grande ocupação territorial do país que hoje põe em risco nosso patrimônio florestal e a qualidade de vida nas cidades, especialmente nas regiões metropolitanas sujeitas à violência endêmica, às más condições habitacionais entre outras carências. O italiano Domenico di Mais tratou de forma otimista a questão do desemprego nos grandes países avançados com a proposta do ócio criativo segundo a qual estaríamos entrando numa sociedade do ócio crescente, na qual poderíamos usar o tempo livre para criar, estudar, fazer coisas que o trabalho diário e longo impedia. O curioso é que o Brasil talvez seja o país com o maior grau de ócio criativo. Temos uma grande população vivendo precariamente, mesmo com pequenos auxílios governamentais, criativa como mostram todas as formas de sociabilidade e de cultura que criamos, do samba ao funk, do futebol à cracolândia.

$\mathrm{Na}$ verdade, os anos 90, marcados pela nossa reentrada no mercado internacional de capitais para escapar da asfixia do não refinanciamento da dívida externa nos anos 80 , fez com que avançássemos apressadamente no quadro de uma globalização e de um neoliberalismo que se parece muito com um tratamento de choque sobre o sistema produtivo e o tecido social, em nome da democracia e dos mercados livres.

No Brasil temos eleições diretas desde a eleição de Collor, mas isto dificilmente caracterizou um avanço do ponto de vista democrático na medida em que convivemos com 
privatização de empresas estatais, indiscriminada abertura comercial, desnacionalizações de empresas privadas nacionais, avanço das novas tecnologias e da reestruturação produtiva sobre o nosso parque industrial ainda não totalmente construído. Em suma, vivemos uma autêntica "destruição criadora" muito distante daquele otimista de que falava Schumpeter. Hoje avançamos na nossa desindustrialização vivendo de exportações intensivas em energia e recursos naturais, nossa classe média regrediu, os poucos ricos tornaram-se muito mais ricos, graças à exploração sem limites do nosso meio ambiente, do uso indevido dos cargos políticos associado ao velho coronelismo ainda vivo e à dilapidação da receita pública graças aos juros que o Banco Central concede aos nossos bancos privados tão tímidos em financiar nosso desenvolvimento.

Assim, não chegamos a construir no Brasil uma sociedade industrializada como as do Norte, não criamos uma sociedade de consumo de massa, mas entramos nessa nossa nãomodernidade líquida diretamente para uma pós-modernidade ambígua, tão ambígua quanto "O ornitorrinco" de que fala Francisco de Oliveira.

É verdade que o governo Lula tem procurado fazer propostas interessantes como a reserva de grande parte dos recursos obtidos como petróleo recém descoberto nas camadas do pré-sal para alavancar projetos sociais e de desenvolvimento. Mas é inegável que a luta política do próximo ano já se instalou e corremos o risco de uma não-governabilidade até as próximas eleições, sem propostas interessantes, capazes de nos dar uma saída para esses impasses. 
